\title{
INFLUENCE OF DENSITY ON THE DURABILITIES OF THREE GHANAIAN TIMBERS
}

\author{
C. Antwi-Boasiako ${ }^{1}$ and A. J. Pitman ${ }^{2}$ \\ ${ }^{1}$ Department of Wood Science and Technology, \\ Kwame Nkrumah University of Science and Technology, Kumasi, Ghana \\ ${ }^{2}$ Forest Products Research Centre, Buckinghamshire Chilterns University College, \\ High Wycombe, Bucks, HP11 2JZ, England, UK \\ (Now with TRADA, High Wycombe, UK)
}

\begin{abstract}
Review of factors influencing wood durability shows although density varies depending on trunk position, its role appears controversial for many timber species. Thus, for the first time, the influence of density on the durability of three Ghanaian timbers (Nauclea diderrichii (de Wild.) Merr., Nesogordonia papaverifera (A. Chev.) R. Capuron and Corynanthe pachyceras Welw.) [a Lesser-Utilized-Species (LUS)] is investigated, particularly for tropical species. Stake density was determined using its corrected oven-dry weight and conditioned volume. Extracted density was based on its density and total extractive content determined using 1:2 ethanol-toluene. Mean weight losses (\%) for stakes from inner and outer heartwoods (IHW and $\mathrm{OHW}$ respectively) of each timber and the middle sapwood (MSW) of C. pachyceras, after exposure to Coriolus versicolor (Linnaeus) Quelet. (a white-rot decay-fungus), were determined and correlated with their densities (unextracted and extracted). Mean densities for $N$. diderrichii, $N$. papaverifera and $C$. pachyceras range between $660-720,640-700$ and $720-820 \mathrm{kgm}^{3}$ respectively for their corresponding $\mathrm{IHWs}$ and $\mathrm{OHWs}$, while MSW of C. pachyceras measures $655-794 \mathrm{kgm}^{3}$. Total extractive contents for the heartwoods of the three species range between 13.29-13.96, 10.18-10.65 and 11.03-14.19\% respectively, while that of $M S W$ of $C$. pachyceras is $9.68 \%$. Relationship between densities at the stem positions and their weight losses resulting from decay by $C$. versicolor shows weak correlations: $R^{2}=0.0095,0.0103$ and 0.1251 for $N$. diderrichii, $N$. papaverifera and $C$. pachyceras respectively for their unextracted densities, and $R^{2}=0.0109,0.015$ and 0.1245 respectively for their extracted densities. Thus, the current study shows density alone has little influence on the decay resistance of the three tropical timbers against bio-deteriogens (e.g. C. versicolor) and that other factors such as extractives play much role in wood durability.
\end{abstract}

Keywords: Coriolus versicolor, Corynanthe pachyceras, durability, extracted density, Nauclea diderrichii, Nesogordonia papaverifera

34 Journal of Science and Technology, Vol. 29, No. 2, Aug., 2009 


\section{INTRODUCTION}

Several authors have examined the relative importance of a number of factors that influence wood durability against bio-deteriogens including fungi. These comprise extractive content and type, lignin content and type, tree type, nitrogen content, physical and other wood properties including density (Garren, 1939; Takahashi and Kishima, 1973; Highley, 1982; Zabel and Morell, 1982; Wong et al., 1983, 1984, 1993; Faix et al., 1985 in Syafii et al., 1988; Yamamoto and Hong, 1994; Suttie and Orsler, 1996). Wood density is a measure of the amount of cell wall per unit volume (Diaz-Vaz et al., 1975; Quirk, 1984 and Saranpää, 2003 in Barnett and Jeronimidis, 2003) whose values are usually given at specific moisture contents; either $0 \%$ or $12 \%$ (Desch and Dinwoodie, 1996). Much controversy exists whether density alone could confer durability on timber. Since high-density timbers have a small voidvolume, this is believed to reduce diffusion of gases through the wood, thereby likely reducing the rate of fungal decay (Yamamoto and Hong, 1994). As a result, several researchers have shown that within species, there is a positive correlation between density and durability. For instance, Wong et al. (1984) examined such a relationship between the density of Eucalyptus delegatensis R.T. Baker and its decay resistance (i.e. durability) against Coriolus versicolor (Fr.) Quel. (a white-rot decayfungus). These authors showed further that position in the stem often influences wood density and durability. Similarly, Yamamoto and Hong (1994) reported good correlations between the wood densities of a greater number of Malaysian tropical hardwoods and their durabilities against the brown-rot fungus (Tyromyces palustris (Berk. et Curt) Murr.) and several white-rot fungi. In contrast, it is often argued that density alone could not influence durability against fungi and other bio-degraders. This is clear when the durabilities of wood species of different densities are compared. Thus, it has been observed that some low-density timbers including Cedrella spp. are more resistant to biodeterioration (e.g. fungal decay) than high- density varieties such as Quercus spp. (Boyce, 1961; Schmidtling and Amburgey, 1977, 1982; Zabel and Morrell, 1992). Cartwright and Findlay (1958) investigated that, in such light timber species, it is the toxic extractives (normally concentrated in the lumina, walls and voids of wood cells) of their heartwoods that confer durability in these regions and also contribute to influence their densities. For that reason, to investigate the influence of density on the durability of wood, then its extracted wood durability should also be examined.

Work on such a relationship between density and durability is non-existent or scant if any for sub-Saharan tropical species. Consequently, the role density plays in imparting durability to three Ghanaian timbers (Nauclea diderrichii (de Wild.) Merr. (kusia/opepe), Corynanthe pachyceras Welw. (pamprana) [family: Rubiaceae] and Nesogordonia papaverifera (A. Chev.) R. Capuron (danta) [family: Tiliaceae]) at their various stem positions is being examined for the first time in this paper. AntwiBoasiako (2004) found the heartwoods of these timbers to be resistant against the white-rot decay-fungus (Coriolus versicolor (Linnaeus) Quelet) under laboratory conditions [EN 113 (Anon., 1982); BS EN 350-1 and 2 (Anon., 1994a,b)] with the following respective durability classes: very durable, moderately durable and durable. Equally reported durable for the first time was the middle sapwood of C. pachyceras. Densities of this and other various stem regions of the three timbers were determined and correlated with their durabilities against $C$. versicolor, as interestingly this has never been established for any Ghanaian wood species.

\section{MATERIALS AND METHODS}

Wood selection and density determination

Wood samples were taken at breast height from about 50-year old single stems of two primary species (i.e. $N$. diderrichii and $N$. papaverifera) from a natural stand in the Nkawie forest district of Ghana. C. pachyceras, a Lesser-Utilized Species (LUS) was sampled at breast height from three stems from three different natural forests: Nkawie, Bekwai, and Offinso (these are 
about $100-160 \mathrm{~km}$ apart) all in the moist semideciduous forest zone with two rainfall peaks (major in May-June, minor in SeptemberOctober). The stems aged between 45-75 years. Blocks were sampled from the inner heartwood (IHW) and outer heartwood (OHW) [3-8 and 19-23 growth rings from the pith, respectively]. Blocks were also taken from the middle sapwood (MSW), 33-37 growth rings from the pith of each of the stems of C. pachyceras. Wood was conditioned at $20^{\circ} \mathrm{C}$ and $65 \% \mathrm{RH}$ until equilibrium moisture content was reached. Ten blocks $(15 \times 10 \times 10 \mathrm{~mm})$ from each radial position in the stems were weighed and their volumes measured using a Mitutoyo digital micrometer. The oven dry weight of each block was determined by calculating the moisture content (mc) of two samples from each respective radial position for each species using the oven-dry method (Desch and Dinwoodie, 1996). This value was used to apply correction for the oven-dry weights of the replicate blocks using the following equation:

$$
C O D W=\frac{100 \times C W}{100+M C}
$$

Where conditioned weight $(\mathrm{CW})=$ block weight at $20^{\circ} \mathrm{C}$ and $65 \% \mathrm{RH}, \mathrm{mc}=$ moisture content of samples. Using the corrected ovendry weights (CODW) and conditioned volumes, it was possible to estimate the density of each block (using Mass/Volume).

Assessment of weight losses of blocks (unextracted) of each species

The durabilities of the individual unextracted blocks were assessed by determining weight losses following their exposure to the fungus (Coriolus versicolor (Linnaeus) Quelet). Blocks were sterilised by autoclaving and 10 blocks from the stem region under investigation of each species were exposed to the decayfungus in a sterile $500 \mathrm{ml}$ decay chambers (Beason jars) containing 3\% malt extract agar (150ml) that had been pre-inoculated 10 days before insertion of the blocks. Blocks were incubated with the decay-fungus at $22 \pm 1^{\circ} \mathrm{C}$ and
$70 \%$ RH for 8 weeks. Following incubation, the replicate blocks were removed from each jar and mycelia cleared from the surface of each stake. The blocks were oven-dried at $105 \pm 2{ }^{\circ} \mathrm{C}$ to their respective constant weights. Percentage weight losses for individual blocks were determined using the equation:

$$
\begin{aligned}
& \% \text { wt loss } \\
& =\left(\frac{\text { Initial corrected oven }- \text { dry weight }- \text { Final oven }- \text { dry weight }}{\text { Initial oven }- \text { dry weight }}\right) \times 100
\end{aligned}
$$

The percentage weight losses for stakes of each species at each stem position were correlated with their unextracted densities to examine the relationship between the two.

\section{The influence of extracted wood density on natural durability}

To determine the relative importance and contribution of extractives and density to wood durability, extracted wood density (i.e. density of wood taken after its extractives were removed) was correlated against the percentage weight losses for blocks exposed to C. versicolor. Methods used to determine extracted densities were based on Chafe's (1987) procedure described in Chafe (1989) using the following equation:

Extracted density

$=$ Unextracted density $\left(\frac{1-\text { Total extracted content }}{100}\right)$

The total extractive contents for wood from the different radial positions in each species were determined using the TAPPI Standard (Anon., 1988; 1996). Statistical comparison of densities and durabilities was made using ANOVA. Extracted densities for each species were also correlated against the percentage weight losses for their respective blocks after exposure to $C$. versicolor.

\section{RESULTS}

Between-species and within-stem density variation

Little variation in density exists at breast height between the three species (Fig. 1). Nonetheless, density is greatest for the inner and outer heart- 
woods (i.e. IHW and OHW respectively) of $C$. pachyceras and least for IHW of $N$. papaverifera. Densities for the two primary species do not vary much. Moreover, with regards to the two heartwoods of each timber, apart from $N$. papaverifera whose $\mathrm{OHW}$ is denser than its IHW, there is no significant difference in density $(\mathrm{p}<0.05)$ between the two positions for $N$. diderrichii and $C$. pachyceras (members of Rubiaceae). However, significant difference exists among the densities (i.e. unextracted) and their extracted densities of each timber (Fig. 1).

\section{Durability variation among the timbers}

Although the difference in densities of the three timbers is little, particularly for the two primary species, much durability variation exists between the timbers. For instance, Fig. 1 again shows that $N$. diderrichii is most durable against $C$. versicolor, as it has the minimum percentage weight loss, while $N$. papaverifera is the least resistant against the decay-fungus even in relation to the middle sapwood (i.e. MSW) from $C$. pachyceras. Moreover, except for IHW of $N$. papaverifera that is more durable than its corresponding $\mathrm{OHW}$, the converse holds true generally for the two other timbers of the Rubiaceae (N. diderrichii and C. pachyceras). Lastly, Fig. 1 shows that despite the small density difference among the various stem positions of the timbers, variation in durability between all the species is significant $(\mathrm{p}<$ $0.05)$.

\section{Total extractive contents of the different} stem positions of the three species

Table 1 shows that, in considering the stem position, for $N$. diderrichii and $C$. pachyceras more extracts were removed from OHW than IHW. However, the total extractive contents of IHW and OHW (i.e. the inner and outer heartwood positions respectively) for $N$. papaverifera as well as $C$. pachyceras are not significantly different $(\mathrm{p}<0.05)$. It is only in $N$. pa-

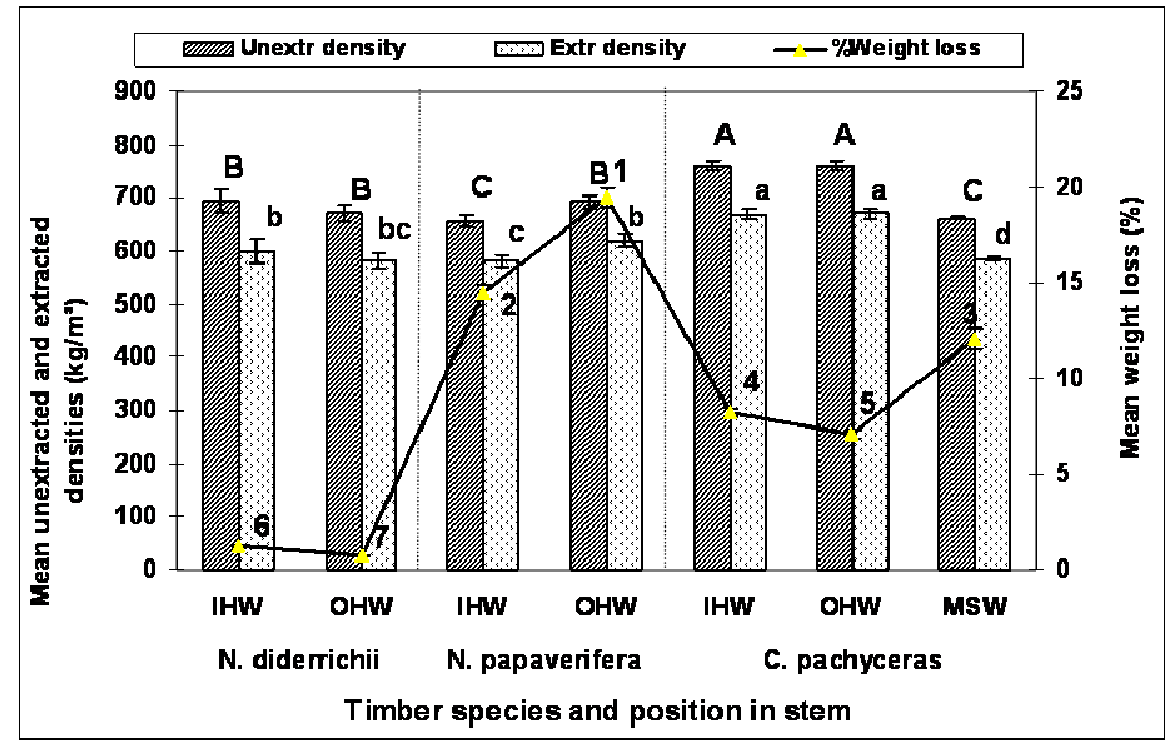

Fig. 1: The influence of wood density (unextracted and extracted) on the durability of $N$. diderrichii, $N$. papaverifera and $C$. pachyceras against $C$. versicolor

Note: $I H W$ and $O H W=$ inner and outer heartwoods respectively. $M S=$ middle sapwood . Bars = standard errors. Bars with the same letters or figures are not significantly different $(p<0.05)$. 

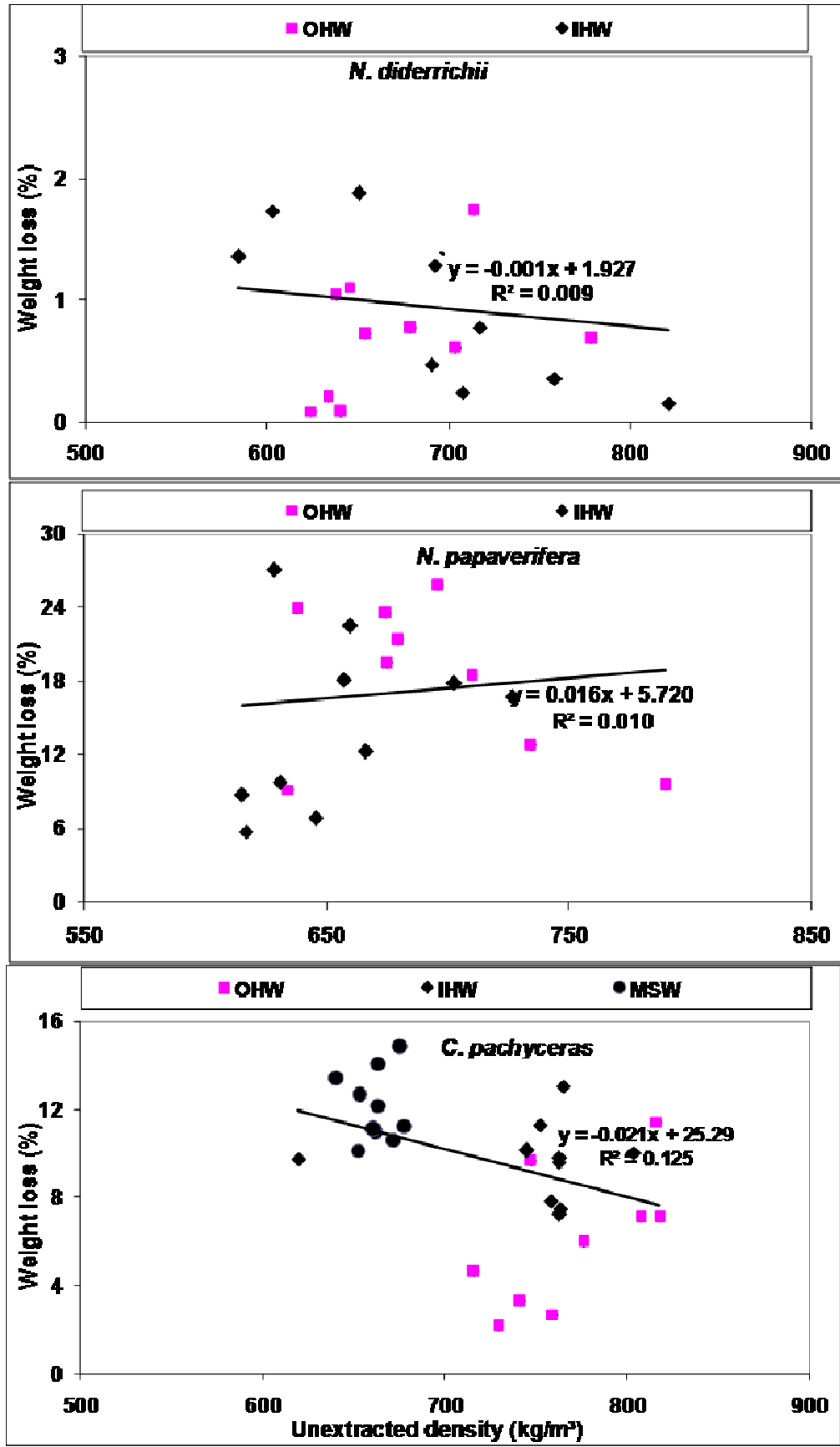

IHW and OHW = inner and outer heartwoods respectively. MSW = middle sapwood

Fig. 2a: Relationship between unextracted densitiy and weight loss resulting from decay against $C$. versicolor for $N$. diderrichii, $N$. papaverifera and $C$. pachyceras

38 Journal of Science and Technology, Vol. 29, No. 2, Aug., 2009 


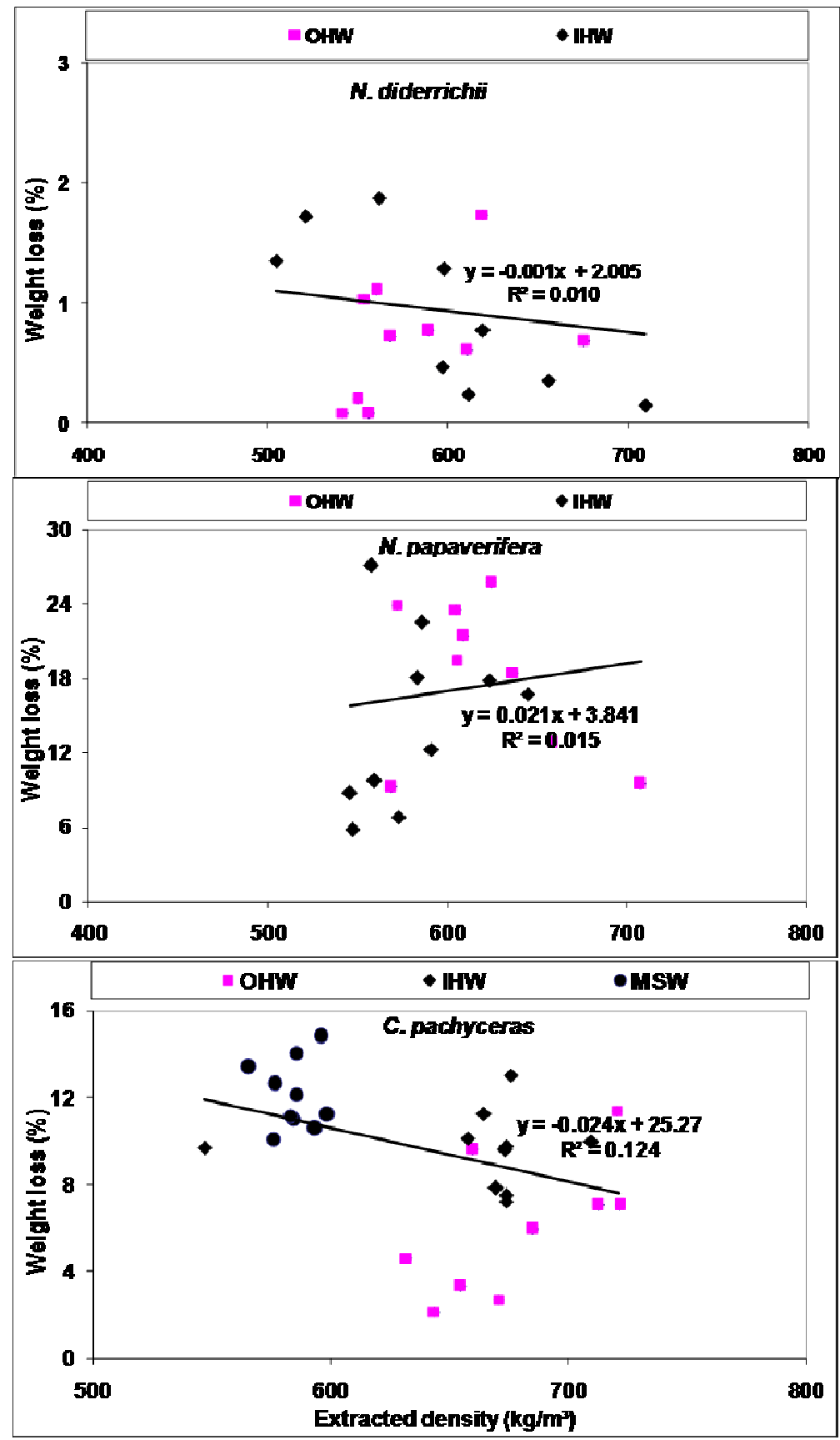

IHW and OHW = inner and outer heartwoods respectively. MSW = middle sapwood

Fig. 2b: Relationship between extracted densitiy and weight loss resulting from decay against C. versicolor for $N$. diderrichii, $N$. papaverifera and $C$. pachyceras 
Table 1: Total extractive contents from the different stem positions of, and $\mathbf{R}^{2}$ values for $N$. diderrichii, N. papaverifera and C. pachyceras

\begin{tabular}{|c|c|c|c|c|}
\hline \multirow[b]{2}{*}{ Timber species } & \multirow{2}{*}{$\begin{array}{l}\text { Position } \\
\text { in stem }\end{array}$} & \multirow{2}{*}{$\begin{array}{l}\text { Mean total extractive } \\
\text { content }(\%)\end{array}$} & \multicolumn{2}{|c|}{$\mathbf{R}^{2}$ values } \\
\hline & & & $\begin{array}{l}\text { Unextracted } \\
\text { density* }\end{array}$ & $\begin{array}{c}\text { Extracted } \\
\text { density }\end{array}$ \\
\hline N. diderrichii & $\begin{array}{l}\text { IHW } \\
\text { OHW }\end{array}$ & $\begin{array}{l}13.29 \pm 0.34^{\mathrm{e}} \\
13.96 \pm 0.71^{\mathrm{d}}\end{array}$ & 0.0095 & 0.0109 \\
\hline$N$. papaverifera & $\begin{array}{l}\text { IHW } \\
\text { OHW } \\
\text { IHW }\end{array}$ & $\begin{array}{l}10.65 \pm 0.63^{b} \\
10.18 \pm 0.19^{b} \\
12.67 \pm 0.51^{c}\end{array}$ & 0.0103 & 0.015 \\
\hline C. pachyceras & $\begin{array}{l}\text { OHW } \\
\text { MSW }\end{array}$ & $\begin{array}{l}12.80 \pm 0.29^{c} \\
9.68 \pm 0.50^{a}\end{array}$ & 0.1251 & 0.1245 \\
\hline
\end{tabular}

Note: Each mean total extractive content is based on two replicates. The same letter $=$ no significant difference $(p<0.05)$ between \% total extractive contents of samples using ANOVA (Source: Antwi-Boasiako, 2004). IHW and OHW = inner and outer heartwoods respectively. MSW = middle sapwood.

paverifera where the extractive content of IHW was greater than that of OHW. For C. pachyceras, the total amount of extractives for MSW (i.e. middle sapwood) is slightly smaller than for the heartwoods.

\section{Correlation between density and durability}

Figs. $2 a$ and $2 b$, on the other hand, show the correlation between wood density (unextracted and extracted respectively) and block weight loss for the three species under investigation resulting from decay by $C$. versicolor (i.e. durability). The two figures show the relationship to be poor for both unextracted and extracted densities, as they all have low $\mathrm{R}^{2}$ values. From the correlations, it appears that the relationship between extracted density and durability is comparatively, slightly weaker (Fig. 2b) than for unextracted density (Fig. 2a). $\mathrm{R}^{2}$ values for the two (2) densities (unextracted and extracted) against weight loss are also presented in Table 1.

\section{DISCUSSION}

\section{Factors that influence wood durability}

Of the numerous wood properties that influence the durability of timber species, the relationship between density and durability is not always clear and has generated much more controversy than any other factor. Nevertheless, such a relationship has been little studied among several timbers globally (especially those from Africa). Based on this, the present work was aimed at investigating the influence of density on the durabilities of three selected Ghanaian hardwoods on exposure to one of the most virulent white-rot decay-fungi, $C$. versicolor. The use of this decay-fungus is imperative as white rots have been found to be more prevalent than brown-rots, with hardwoods being more susceptible to white-rot attack (Savory, 1954 in Daniel and Nilsson, 1998). White-rot decayfungi are thus specified for use when testing hardwood durability. Antwi-Boasiako (2004) found that the heartwoods of the three timbers proved durable and were thus employed in establishing the relationship between their densities and durabilities, as the total amount of biocidal extractives in heartwoods contribute to impart durability to wood. The middle sapwood (MSW) of $C$. pachyceras has been found durable by the same author and was also employed to examine the density-durability relationship in sapwoods, which are often hardly durable (Desch and Dinwoodie, 1996). 
Mean densities (unextracted and extracted) at different stem positions of the three species.

Mean densities recorded for the three timbers in the present study from only their bases differ from published figures. For example, 620$720 \mathrm{~kg} / \mathrm{m}^{3}$ was recorded for the primary species (N. diderrichii and $N$. papaverifera), which is quite different from the published value (i.e. $750 \mathrm{~kg} / \mathrm{m}^{3}$ ) reported by Bailey (1933) in Coday and Maun (1994). For C. pachyceras, Kribs (1959) reported about $867 \mathrm{~kg} / \mathrm{m}^{3}$ (i.e. $45 \mathrm{lb} /$ cu.ft), while $641-828 \mathrm{~kg} / \mathrm{m}^{3}$ was currently recorded. The present density values appear unsurprisingly lower than those in literature, as the latter were taken under conditioned weight and volume as well as from unspecified stem positions and stake conditions, whereas the current assessments were based on corrected dry weights and conditioned volume of stakes of each species. The corrected oven-dry weights were employed in order not to destroy the extractives in each stake as result of volatilization through oven-drying, as the stakes were exposed to the decay-fungus after their weight and density determinations. Although little is known about $C$. pachyceras (LUS), its density has been found to be the greatest among the three timbers, even greater than its traditionally known related primary species (i.e. $N$. diderrichii) of the same family (i.e. Rubiaceae). Slight density variation exists at breast height among stem positions of the three species. For example, no variation exists between the inner heartwood (IHW) and outer heartwood (OHW) of $N$. diderrichii and $C$. pachyceras. It is only in $N$. papaverifera (the Tiliaceae) that $\mathrm{OHW}$ is slightly denser than IHW. For $C$. pachyceras, its middle sapwood (MSW) is found to be less dense than its heartwoods. In a previous study, Antwi-Boasiako (2004) reported that there is a tendency for density to decrease from IHW to the outer sapwood (OSW) at all axial positions of the three timbers, especially for the two primary species. Wong et al. (1993) also showed that basic density ("extracted" and "unextracted") generally increased outward from the pith (both intra- and inter- incrementally). All the same, density patterns from the pith outward of hardwoods often appear less consistent than in softwoods as in the present situation. For example, Taylor and Wooten (1973) observed at the bases of Platanus oocidentalis L., Quercus phelos L. and Salix nigra Marsh that density decreased from the pith outwards (with a slight contrast at the crowns). In hardwoods, as it is clearly the case in the current study, such variations are often not uniform.

\section{Stem density variation and the contribution by extractives}

Several researchers have reported a number of factors that influence density variation in timber. Brown et al. (1952) and Cartwright and Findlay (1958) have found the influence of density as a reflection of the amount of cell wall per unit volume of wood, which is also significantly influenced by extractive (and ash) components. The total extractive content data similarly reveal that it is likely the presence of extractives could be responsible for the density variations in the different stem regions of each timber. This is particularly the case for $N$. papaverifera (where $\mathrm{OHW}$ density is greater than IHW's) and C. pachyceras (whose heartwoods are denser than MSW). Similarly, Brown et al. (1952) recognized that extractives contribute appreciably to influence wood density by making up large proportion of the weight of several heartwoods (i.e. about $20 \%$ by weight of ovendry weight). It is therefore expected that extractives influence wood density and contribute to the roles density plays in many timber characteristics including durability. Extractives' contribution could be significant because they have been examined to confer natural durability on many timber species including teak and African mahogany (Syafii et al,. 1987; Yamamoto and Hong, 1994; Suttie and Orsler, 1996). Wong et al. (1993) revealed that durability was influenced by density in extracted northern hemisphere conifers and eucalypt species. This and previous investigations by Antwi-Boasiako (2004) have likewise confirmed that densities of the three timbers drastically reduced after 
their toxic secondary metabolites (especially extractives) were removed from their stakes. Apart from influencing density, it should be noted that removal of such biocidal extractives by solvents often damages the cell structure and the organization of cell wall components, which are often injurious to stakes. These could assist to make extracted woods more susceptible to deterioration.

\section{Relationship between wood density and du- rability}

The fact that the densities at different stem positions appear not to differ greatly does not mean there cannot be durability variations between them. Such an observation is not unique to these Ghanaian wood species only. Several researchers including Boyce (1961), Schmidtling and Amburgey (1977; 1982), Nilsson and Daniel (1992) and Zabel and Morrell (1992) have shown similarly that the relationship between density and decay resistance does not always hold true. That is, a good correlation between the two does not always exist for a number of species. For instance, the heartwood density of $N$. papaverifera compares with those of $N$. diderrichii and MSW of $C$. pachyceras yet the durability of $N$. papaverifera is significantly lower than those for these stem positions of the two members of the Rubiaceae (i.e. $N$. diderrichi and $C$. pachyceras). This shows that besides density, other factors contribute to influence wood durability. Wilcox (1965), Takahashi and Kishima (1973), Highley (1982), Wong et al. (1983; 1984), Faix et al. (1985) in Syafii et al. (1988) as well as Yamamoto and Hong (1994) reported such factors include lignin and extractives. For extractives, apart from their contents, extractive type could play a vital role. For instance, the extractive content of $N$. papaverifera does not vary greatly from those from the other two species, yet durability varies greatly among the three species. Intraspecifically, the extractive contents for IHW and OHW of $N$. papaverifera and $C$. pachyceras are also not significantly different $(\mathrm{p}<0.05)$, however, their durabilities vary. Suttie and Orsler (1996), in a related study, dem- onstrated that extractive type influences heartwood durability of $\mathrm{N}$. diderrichii against $\mathrm{Co}$ niophora puteana (Schum. Fr) P. Karsten (a brown-rot decay-fungus).

When the influence of the within-species density on durability is examined, weak correlations exist across the stems of the timbers. This work lends more support to the fact that density, on its own, has little influence on durability, as has been reported for many timbers such as beech (Fagus sylvatica L.) and black oak (Quercus sp.) (Boyce, 1961; Schmidtling and Amburgey, 1977 and 1982; Zabel and Morrell, 1992). However, this is against the backdrop that other authors such as Wong et al. (1993) have found a good correlation between density and durability within other species including northern hemisphere conifers and eucalypts. They observed the correlation generally increased outward from the pith. Nonetheless, the present work revealed the trend is not consistent for the tropical hardwoods examined.

\section{Extracted density and wood durability}

Moreover, since the extractive content of the wood contributes to influence density, it was appropriate the total extractives of the blocks of each species were determined and employed to establish the relationship between extractivefree densities of the timbers and their durabilities. The overall weak correlations also observed for their weight losses as against those of their extracted densities establish that density is of little significance in influencing their durabilities against the decay-fungus. However, it should be emphasized that the extractive-free density for each species was calculated through correction as recommended by Chafe (1989). It is therefore possible that actually extracting blocks to remove extractives might have a significant influence on their decay resistance. This was demonstrated by Syafii et al. (1987) and Suttie and Orsler (1996) when they removed extractives in several timbers including ulin (Eusideroxylon zwageri $\mathrm{T} \& \mathrm{~B}$ ), which is known to be one of the most durable timbers (Syafii et al., 1987). Their durabilities were severely influenced so were the water- and 
methanol-extracted stakes of the three Ghanaian hardwoods on exposure to $C$. versicolor (Antwi-Boasiako, 2004).

The present work and several other studies suggest that extractives are by far a more important factor than density regarding their contribution to wood durability (i.e. against decay). Thus, density alone is not a good indicator of durability. Such a result is not unusual. Akhter and Hale (2002) likewise observed that density is not correlated with durability in Douglas fir (Pseudotsuga menziesii (Mirb.) Franco) against $C$. puteana $(\mathrm{r}=0.11)$. Unsurprisingly, a number of high-density woods including $F$. sylvatica, red and black oak (Quercus spp.) and maple (Acer spp.) have lower durabilities, while many low density types such as redwood (Sequoia sempervirens (D. Don) Endl), cedars (Cedrela spp.) and Catalpa spp. are highly durable (Boyce, 1961; Schmidtling and Amburgey, 1977; 1982). The present investigation presupposes that density in itself is a poor determinant of durability for the tropical hardwoods studied.

\section{CONCLUSION}

The present study has shown the mean densities of the three species at breast height vary in this decreasing order: C. pachyceras $>N$. diderrichii $>N$. papaverifera. The difference in density between the latter two primary species is significant $(p<0.05)$ contrary to existing data. Nevertheless, slight density variation exists, if any, between the two heartwood positions (i.e. IHW and OHW) for the species, unlike their inter-specific and intra-specific durabilities, which are all very significant $(p<0.05)$. Importantly, correlation between density and durability is weak for all the three species; the relationship is weaker for extracted density than for unextracted density and durability.

Total extractive content has been found to influence wood durability instead of density, which has little influence. This suggests that other factors are more responsible for the differences in durability between and within the timbers. Although extractive content could influence durability, extractive type would be more important a factor to consider since its content slightly varies within each stem yet enormous durability variation exists between the timbers.

\section{ACKNOWLEDGEMENT}

We are grateful to the staff of The School of Plant Sciences of The University of Reading (Reading, UK), Forest Products Research Centre (FPRC) of Buckinghamshire Chilterns University College (High Wycombe, UK), The Royal Botanic Gardens (KEW, UK) for the laboratories and equipment they made available for the execution of this work. We also thank the Government of Ghana for the financial support for the study in England, UK.

\section{REFERENCES}

Akhter, S. and Hale, M. D. C. (2002). Variation in Natural Durability of British Grown Douglas Fir (Pseudotsuga menziesii (Mirb.) Franco). Part 1. Effect of Density and Growth Rate. IRG/WP. Paper Prepared for the 33rd Annual Mtg., Cardiff, Wales (UK). 12-17 May, 2002. IRG Sec't, Stockholm, Sweden.14pp.

Anon. (1982). EN 113:6009. Wood Preservatives. Determination of the Toxic Values Against Wood-destroying Basidiomycetes Cultured on an Agar Medium.

Anon. (1988). ASTM: T 264 om-88. Preparing of Wood for Chemical Analysis. Approved by Pulp Properties Committee of the Process and Product Quality Division. Technical Assoc. of Pulp \& Paper Industry (TAPPI). 2pp.

Anon. (1994a). BS EN 350-1 Durability of Wood and Wood-based Products - Natural Durability of Solid Wood. Part 1. Guide to the Principles of Testing and Classification of the Natural Durability of Wood.

Anon. (1994b). BS EN 350-2 Durability of Wood and Wood-based Products - Natural Durability of Solid Wood. Part 2. Guide to Natural Durability and Treatability of Selected Wood Species of Importance in Europe. 
Anon. (1996). ASTM: Designation D. 1105-96. Standard Test Method for Preparation of Extractive-free Wood. Technical Assoc. of Pulp \& Paper Industry (TAPPI). Standard Method T12 os-75. P.178.

Antwi-Boasiako, C. (2004). Assessment of Anatomy, Durability and Treatability of Two Tropical Lesser-Utilized Species and Two Related Species from Ghana. PhD Thesis (2004) submitted to The University of Reading, Reading, England (UK). 319pp.

Barnett, J. R. and Jeronimidis, G. (2003). Wood Quality and its Biological Basis. Blackwell Publishing Ltd., Oxford, UK. CRC Press LLC, USA and Canada. 225pp.

Boyce, J. S. (1961). Forest Pathology. $3^{\text {rd }}$ ed. McGraw-Hill Book Co. Ltd. New York. S.572.

Brown, H. P., Panshin, A. J. and Forsaith, C. C. (1952). Textbook of Wood Technology. Vols. 1\&2. McGraw-Hill Book Company Inc. London.

Cartwright, K. St. G. and Findlay, W. P. K. (1958). Decay of Timbers and its Prevention. $2^{\text {nd }}$ Edn. 322pp.

Chafe, S. C. (1989). Observations on the Relationship between Wood Durability and Density. J. Inst. Wood Sc. 11 (5): 182-185.

Clark, J. W. and Scheffer, T. C. (1983). Natural Decay Resistance of the Heartwood of coastal redwood Sequoia sempervirens (D. Don) Endl. Forest Products Journal, 33 (5): 15-20.

Coday, A. E. and Maun, K. W. (1997). Identification of Hardwoods. A Microscopic Key. BRE Publications, Garston, 236pp.

Daniel, G. and Nilsson, T. (1998). Developments in the Study of Soft Rot and Bacterial Decay. Pp. 37-62. In: Forest Products Biotechnology. Ed: Highley, T. L.

Desch, H. E. and Dinwoodie, J. M. (1996). TIMBER: Structure, Properties, Conversion and Use. $7^{\text {th }}$ edn. McMillan Press Ltd., UK. 306pp.
Garren, K. H. (1939). Studies on Polyporus abientinus. 111. The Influence of Certain Factors on the Rate of Decay of Loblolly Pine Sapwood. J For., 37: 319-323.

Highley, T. L. (1982). Influence of Type and Amount of Lignin on Decay by Coriolus versicolor. Can. J. For. Res., 12: 435-438.

Kribs, D. A. (1959). Commercial Foreign Woods on the American Market. Ann Arbor. Mich., Edwards Brothers.

Nilsson, T. and Daniel, G. (1992). On the Use of \% Weight Loss as an Assessment for Expressing Results of Laboratory Decay Experiments. Working Group II; Fundamentals of Testing Document No.: IRG/ WP/2394-92. IRG Sec't., Stockholm, Sweden. $5 \mathrm{pp}$.

Quilho, T. and Pereira, H. (2001). Within- and Between-tree Variation of Bark Content and Wood Density of Eucalyptus globules in Commercial Plantations. IAWA Journal, 22(3): 255-265.

Saranpää, P. (2003). Wood Density and Growth (Chpt. 4). In: Wood Quality and its Biological Basis. Blackwell Publishing Ltd., Oxford, UK. CRC Press LLC, USA and Canada. Eds. J. R. Barnett \& G. Jeronimidis (2003). 225pp.

Schmidtling, R. C. and Amburgey, T. L. (1977). Growth and Wood Quality of Slash Pines after Early Cultivation and Fertilization. Wood Sci. 9: 154-159.

Schmidtling, R. C. and Amburgey, T. L. (1982). Genetic Variation in Decay Susceptibility and its Relationship to Growth and Specific Gravity in Loblolly Pine. Holzforschung 36: 159-161.

Suttie, E. D. and Orsler, R. J. (1996). The Influence of Natural Extractives of opepe (Nauclea diderrichii) and African padauk (Pterocarpus soyauxii) Timbers on their Durability. Section 3. Wood Protection Chemicals. IRG/WP 96-30098. Paper Prepared for the $27^{\text {th }}$ Annual Mtg., Gosier, 
Guadeloupe. 19-24 May, 1996. IRG Sec't. Stockholm, Sweden. Pp.1-15.

Syafii, W., Samejima, M. and Yoshimoto, T. (1987). The Role of Extractives in Decay Resistance of Ulin Wood (Eusideroxylon zwageri T. et B.). Bull. Tokyo Univ. For., 77. Pp. 1-8.

Syafii, W., Samejima, M. and Yoshimoto, T. (1988). The Role of Lignin on Decay Resistance of Ulin (Eusideroxylon zwageri $\mathrm{T}$. et B.) to Wood-rotting Fungi. Bull. Tokyo Univ. For., 79: 119-126.

Syafii, W., Samejima, M. and Yoshimoto, T. (1988). The Effect of Lignin Structure on Decay Resistance of Some Tropical Hardwoods. Bull. Tokyo Univ. For., 80: 69-77.

Takahashi, M. and Kishima, T. (1973). Decay Resistance of Sixty-five Southeast Asian Timber Specimens in Accelerated Laboratory Tests. Tonan Ajia Kenkyu (The Southeast Asian Studies) 10(4): 525-541.

Taylor, F. W. and Wooten, T. E. (1973). Wood Property Variation of Mississippi Delta Hardwoods. Wood Fiber 5: 2-13.
Wong, A. H. H., Wilkes, J. and Heather, W. A. (1983). Influence of Wood Density and Extractive Content on the Decay of the Heartwood of Eucalyptus delegatensis R.T. Baker. J. Inst. Wood Sci. 54: 261-263.

Wong, A. H. H., Wilkes, J. and Heather, W. A. (1984): Inter- and Intra-incremental Variation in Basic Density, Extractive Content, and Decay Resistance in Eucalyptus delegatensis. Mat. u. Org. 19: 141-148.

Wong, B. M., Knoll, C. S. and Roy, D. N. (1993): The Chemistry of Decayed Aspen Wood and Perspectives on its Utilization. Wood Science Technology, 27(6): 439-448.

Yamamoto, K. and Hong, L. T. (1994): A Laboratory Method for Predicting the Durability of Tropical Hardwoods. Japan International Research Centre for Agricultural Sciences. JARQ 28(4): 268-275.

Zabel, R. A. and Morrell, J. J. (1992): Wood Microbiology. Decay and its Prevention. $1^{\text {st }}$ edn. Academic Press Inc., London NW1 7DX. 47pp. 